\title{
THE EFFECT OF DIFFERENT COOKING PROCESS ON MICROBIOLOGICAL QUALITY OF KOKOREC
}

\author{
Bilal Bilgin $^{1}$, Neslihan Makarnacı ${ }^{2}$ İbrahim Palabiyik ${ }^{3}$ \\ ${ }^{1}$ Associate Professor, Department of Food Engineering, Namık Kemal University, Tekirdağ, Turkey \\ ${ }^{2}$ M.Sc., Department of Food Engineering, Namık Kemal University, Tekirdağ, Turkey \\ ${ }^{3}$ Assistant Professor Department of Food Engineering, Namık Kemal University, Tekirdağ, Turkey \\ bbilgin@nku.edu.tr
}

\begin{abstract}
In this research, totally 180 kokorec samples which 60 raw, 60 grilled and 60 tandir ovened were investigated certain microbiological parameters. Average total mesophilic aerobe bacteria (TMAB), coliform and coagulase (+) $S$. aureus counts were found as $3.8 \times 10^{7}, 2.2 \times 10^{4}$ and $3.2 \times 10^{3} \mathrm{cfu} / \mathrm{g}$ in raw samples, respectively. Also, the results were found to be positive for E. coli, E. coli 0157:H7, C. perfringens and Salmonella spp. as 60 (100\%), 9 (15\%), 18 (45\%) and 54 (90\%) in raw samples, respectively. On the other hand, it was determined that average TMAB, coliform and coagulase (+) S. aureus counts in grilled and tandir ovened samples as $1.2 \times 10^{3}, 5.7 \times 10^{1}, 1.2 \times 10^{2}$ cfu/g and $2.3 \times 10^{4}, 8.6 \times 10^{1}, 3.1 \times 10^{2}$ cfu/g. respectively. No E. coli 0157:H7 and C. perfringens were determined in grilled and tandir ovened kokorec samples, while the results were only found to be positive for E. coli and Salmonella spp. as $3(5 \%)$ in these samples. Also, it was found to be positive for E. coli as 24 (40\%) and Salmonella spp. as $42(\% 70)$ in tandir ovened kokorec samples.
\end{abstract}

Keywords: Food Hygiene, Public Health, Offal, Kokorec, Microbiological Quality

\section{INTRODUCTION}

Meat is obtained from sheep and cattle farm animals, poultry, seafood and of various game animals of the skeletal muscle and internal organs by slaughter, fragmentation and processing. Offal also parts of a meat animal which is used as food but which are not skeletal muscle and it covers insides including the heart, liver, and lungs, all abdominal organs and extremities, tails, feet, and head including brains and tongue [1]. Although internal organs of slaughter animals contain more water, contains less fat compared to red meat. On the other hand, while red meat contain very little carbohydrate, most of the internal organs provides high carbohydrate rate [2]. While not achieving a strong acceptance by consumer, offal represent an excellent source of proteins, vitamins, and minerals [3].

Kokorec, an offal product, is prepared from fresh and washed lamb or mutton intestines around mesenterial fat and cooked in different ways; grilled, fried, boiled or tandoori cooked. The most popular cooked process is that wrapped intestines around a skewer are grilled horizontally on a charcoal fire which gives it an extra rich flavor and chopped, seasoned with salt, pepper and oregano, and served on bread.

It has been reported by various researchers that meat and meat products may contain pathogens such as Clostridium, Campylobacter, Listeria, E. coli, Salmonella, Brucella and Staphylococcus because of the ruminants as it includes various pathogens of intestinal flora $[4,5,6]$. It may include the potential health risks if not carried out completely the essential hygiene and sanitation conditions and/or adequate cooking process during the preparation of the intestine. These health risks are microbiological character. In Turkish Food Codex Communiqué on Microbiological Criteria, in meat and meat products, Salmonella, E. coli O 157 and Listeria monocytogenes (L. monocytogenes) must be negative in $25 \mathrm{~g}$ sample and the number of total mesophilic aerobic bacteria (TAMB) must be no more than 5x106 g sample [7].

In this study, it was investigated the certain microbiological parameters of raw kokorec samples made in a specific slaughterhouse and their samples prepared with two different cooking methods as grilled and tandir ovened.

\section{MATERIALS AND METHODS}

In October-April period, it was taken monthly 60 kokorec samples each about $1 \mathrm{~kg}$ cleaned and skewered. Each sample was prepared in 3 different skewers, totally 120 samples. First skewers for raw samples, second and third skewers after grilled and tandir ovened were brought to the laboratory under sterile bags and cold chain. Samples were stored in the refrigerator at $4 \pm 2{ }^{\circ} \mathrm{C}$ during the analysis. Some physicochemical properties of the raw kokorec samples are summarized in Table 1.

Dry matter, protein content, fat rate and the amount of ash of example were determined according to ISO [8, 9, 10, 11]. For microbiological analysis, sample preparation, TMAB, coliform and E. coli, Salmonella, S. aureus and $C$. perfringens were determined according to FDA BAM [12, 13, 14, 15, 16, 17]. Also E. coli 0157:H7 was determined according to Luciano et al., [18]. 
Table-1: Some physical-chemical properties identified in samples of raw kokorec $(n=60)$

\begin{tabular}{lcccc}
\hline & $\begin{array}{c}\text { Dry } \\
\text { Matter }(\boldsymbol{\%})\end{array}$ & $\begin{array}{c}\text { Fat } \\
(\boldsymbol{\%})\end{array}$ & $\begin{array}{c}\text { Protein } \\
(\boldsymbol{\%})\end{array}$ & $\begin{array}{c}\text { Ash } \\
(\boldsymbol{\%})\end{array}$ \\
\hline Maximum & 23.65 & 8.12 & 14.34 & 1.31 \\
Minimum & 20.47 & 6.12 & 11.57 & 1.08 \\
Average & 21.85 & 7.00 & 12.97 & 1.20 \\
\hline
\end{tabular}

$\mathrm{n}=$ the number of examined samples

\section{RESULTS}

Microbiological quality characteristics of raw, grilled and tandir ovened samples are presented in Table 2. The number of TAMB were found between $1.2 \times 106$ and $1.2 \times 108$, and to average of $3.8 \times 107 \mathrm{cfu} / \mathrm{g}$ in raw sample, between $1.1 \mathrm{x}$ 103 and $6.0 \times 104$ and to average $2.3 \times 104 \mathrm{cfu} / \mathrm{g}$, respectively.
Coliform bacteria counts were found between 1,0x103 and $8,4 \times 104$, and to average of $2,2 \times 104 \mathrm{cfu} / \mathrm{g}$ in the raw samples. Also coliform bacteria counts were found as

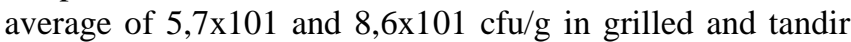
ovened samples, respectively.

Coagulase (+) S. aureus was detected between $1.5 \times 103$ and $9.6 \times 103,<1.0 \times 101$ and $8.9 \times 102$, and $2.5 \times 101$ and $3.1 \times$ 102 in raw, grilled and, tandir ovened samples, respectively. While E. coli was detected in all raw samples, E. coli 0157:H7, C. perfringens and Salmonella were detected in 9 (15\%), $18(45 \%)$ and $54(90 \%)$, respectively. As E. coli and Salmonella were detected in $3(5 \%)$ in grilled samples, E. coli $0157: \mathrm{H} 7$ and $C$. perfringens were not detected in any of the grilled samples. On the other hand, it was detected $E$. coli in $24(40 \%)$ and Salmonella in $42(70 \%)$ in tandir ovened samples. Also E. coli $0157: \mathrm{H} 7$ and C. perfringens were not detected in any of the tandir ovened samples.

Table-2. The microbiological characteristics of raw, grilled and tandir ovened kokorec samples $(\mathrm{n}=60)$

\begin{tabular}{|c|c|c|c|c|c|c|c|}
\hline Samples & $\mathbf{n}^{*}$ & Microorganism & Maximum & Minimum & Average & Positive number $^{+}$ & $(\%)$ \\
\hline \multirow[b]{2}{*}{ Raw } & \multirow[b]{2}{*}{60} & $\begin{array}{l}\text { TMAB }(\mathrm{cfu} / \mathrm{g}) \\
\text { Coliform }(\mathrm{cfu} / \mathrm{g}) \\
\text { S. aureus }(\mathrm{cfu} / \mathrm{g})\end{array}$ & $\begin{array}{l}1.2 \times 10^{8} \\
8.4 \times 10^{4} \\
9.6 \times 10^{3}\end{array}$ & $\begin{array}{l}1.2 \times 10^{6} \\
1.0 \times 10^{3} \\
1.5 \times 10^{3}\end{array}$ & $\begin{array}{l}3.8 \times 10^{7} \\
2.2 \times 10^{4} \\
3.2 \times 10^{3}\end{array}$ & & \\
\hline & & $\begin{array}{l}\text { E. coli } \\
\text { E. coli } 0157: \mathrm{H} 7 \\
\text { C. perfringens } \\
\text { Salmonella spp. }\end{array}$ & & & & $\begin{array}{l}60 / 60 \\
9 / 60 \\
18 / 60 \\
54 / 60\end{array}$ & $\begin{array}{l}(100) \\
(15) \\
(45) \\
(90)\end{array}$ \\
\hline \multirow[b]{2}{*}{ Gerilled } & \multirow[b]{2}{*}{60} & $\begin{array}{l}\text { TMAB }(\mathrm{cfu} / \mathrm{g}) \\
\text { Coliform }(\mathrm{cfu} / \mathrm{g}) \\
\text { S. aureus }(\mathrm{cfu} / \mathrm{g})\end{array}$ & $\begin{array}{l}5.5 \times 10^{3} \\
5.2 \times 10^{2} \\
8.9 \times 10^{2}\end{array}$ & $\begin{array}{l}<1.0 \times 10^{1} \\
<1.0 \times 10^{1} \\
<1.0 \times 10^{1}\end{array}$ & $\begin{array}{l}1.2 \times 10^{3} \\
5.7 \times 10^{1} \\
1.2 \times 10^{2}\end{array}$ & & \\
\hline & & $\begin{array}{l}\text { E. coli } \\
\text { E. coli } 0157: \mathrm{H} 7 \\
\text { C. perfringens } \\
\text { Salmonella } \mathrm{spp} .\end{array}$ & & & & $\begin{array}{l}3 / 60 \\
0 / 60 \\
0 / 60 \\
3 / 60\end{array}$ & $\begin{array}{l}(5) \\
(0) \\
(0) \\
(5)\end{array}$ \\
\hline \multirow{2}{*}{$\begin{array}{l}\text { Tandir } \\
\text { Ovened }\end{array}$} & \multirow[b]{2}{*}{60} & $\begin{array}{l}\text { TMAB }(\mathrm{cfu} / \mathrm{g}) \\
\text { Coliform }(\mathrm{cfu} / \mathrm{g}) \\
\text { S. aureus }(\mathrm{cfu} / \mathrm{g})\end{array}$ & $\begin{array}{l}6.0 \times 10^{4} \\
6.4 \times 10^{2} \\
7.6 \times 10^{2}\end{array}$ & $\begin{array}{l}1.1 \times 10^{3} \\
<1.0 \times 10^{1} \\
2.5 \times 10^{1} \\
\end{array}$ & $\begin{array}{l}2.3 \times 10^{4} \\
8.6 \times 10^{1} \\
3.1 \times 10^{2}\end{array}$ & & \\
\hline & & $\begin{array}{l}\text { E. coli } \\
\text { E. coli } 0157: \mathrm{H} 7 \\
\text { C. perfringens } \\
\text { Salmonella } \mathrm{spp} \text {. }\end{array}$ & & & & $\begin{array}{l}24 / 60 \\
0 / 60 \\
0 / 60 \\
42 / 60 \\
\end{array}$ & $\begin{array}{l}(40) \\
(0) \\
(0) \\
(70)\end{array}$ \\
\hline
\end{tabular}

*n: examined sample number

${ }^{+}$Numbers detected in the detection limit was evaluated as positive.

\section{DISCUSSION}

In a research, Salmonella was identified in $2(4 \%)$ raw and in $6(12 \%)$ cooked offal samples consists of brains, cheeks, tongue, tripe and liver [19]. Also Ulutürk were found positive for Salmonella in $40 \%$ brain, $24 \%$ spleen, $20 \%$ liver, $20 \%$ lungs, $20 \%$ tripe and $12 \%$ heart out of 150 raw offal samples [20]. According to the results of another research, while TMAB, coliform and E. coli were detected as between 105-107; 104-107 and 101-106 cfu/g in raw kokorec samples, respectively. In the same study, $S$. aureus and Salmonella were not detected in any of the samples [21]. Hampikyan et al. found TMAB, coliform, E. coli and
S. aureus as between $5.3 \times 103-7.0 \times 105$; <1.0x101$2.1 \times 104 ;<1.0 \times 101-6.6 \times 102$ and $<1.0 \times 102-4.8 \times 103 \mathrm{cfu} / \mathrm{g}$ in 15 grilled kokorec samples presented for consumption in Istanbul, respectively. Also, there was not detected Salmonella in any of the samples in the same study [22]. In a research on microbiological quality of kokorec presented in Afyonkarahisar for consumption, TAMB, Enterobacteriaceae, coliform, E. coli, Enterococcus spp., Staphylococcus/Micrococcus and yeasts and moulds were found as $1.9 \times 106,2.2 \times 104,2.7 \times 102,1.2 \times 102,1.5 \times 104$, $7.1 \times 102$ and $7.8 \times 105 \mathrm{cfu} / \mathrm{g}$, respectively [23]. 
In this research, the presence of $E$. coli in all, E. coli O157: $\mathrm{H} 7$ in $15 \%(9 / 60)$, C. perfringens in $45 \%(27 / 60)$ and Salmonella in $90 \%(54 / 60)$ raw samples indicates that the cleaning was not enough during the sample preparation. Also, according to these results, it has been shown that the most effective cooking process is grilled. The presence of $E$. coli in 40\% (24/60) and Salmonella in 70\% (42/60) demonstrated that the heat treatment was not enough in tandir ovened cooking.

\section{CONCLUSIONS}

It is necessary to comply with the hygiene processes during the preparation and cleaning of intestine because of kokorec is likely to be contaminated with enteric microorganisms as of natural structure. In addition, the temperature should be to reach the midpoint of product in the cooking process for inhibition of pathogens likely to be found in raw product.

\section{REFERENCES}

[1] Gökalp H. Y., Kaya M., and Zorba Ö., 1994. Et Ürünleri İşleme Mühendisliği. Atatürk Üniv. Yayın No: 786, s:24.

[2] Demirci, M. 2002. Beslenme. Rebel Yayıncılık, İstanbul, s:73.

[3] Mullen, A.M., Alvarez, C., 2016. Offal: Types and composition. Reference Module in Food Science, from Encyclopedia of Food and Health, Pages 152-157

[4] Shimoni, E., Labuza, T.P., 2000. Modeling pathogen growth in meat products: future challenges. Trends in Food Sci. \& Tech. 11: 394-402.

[5] Leclerc, V., Dufour, B., Lombard, B., Gauchard, F., Garin-Bastuji, B., Salvat, G., Brisabois, A., Poumeyrol, M., De Buyser, M.L., Gnanou-Besse, N., Lahellec, C., 2002. Pathogens in meat and milk products: surveillance and impact on human health in France. Livestock Production Sci. 76: 195-202.

[6] Pointon, A., Jenson, I., Jordan, D., Vanderlinde, P., Slade, J., Sumner, J., 2006. A risk profile of the Australian red meat industry: Approach and management. Food Control 17: 712-718.

[7] TGK, 2011. Türk Gıda Kodeksi Yönetmeliği. Resmi Gazete, 10/Subat/2000, sayı:23960. Ankara: Başbakanlık Basımevi.

[8] ISO 1442:1997. Meat and meat products-Determination of moisture content (Reference method), ISO, Geneva, Switzerland.

[9] ISO 937:1978. Meat and meat products-Determination of nitrogen content (Reference method), ISO, Geneva, Switzerland.

[10] ISO 1443:1973. Meat and meat products-Determination of total fat content, ISO, Geneva, Switzerland.

[11] ISO 936:1998. Meat and meat products-Determination of total ash. ISO, Geneva, Switzerland.

[12] FDA BAM 1998a. Bacteriological Analytical Manual, Edition 8, Revision A. Chapter 1. Food Sampling and Preparation of Sample Homogenate.

http://www.fda.gov/Food/FoodScienceResearch/Laborat oryMethods/ucm063335.htm

[13] FDA BAM 1998b. Bacteriological Analytical Manual, Edition 8, Revision A. Chapter 3. Aerobic Plate Count.
http://www.fda.gov/Food/FoodScienceResearch/Laborat oryMethods/ucm063346.htm

[14] FDA BAM 1998c. Bacteriological Analytical Manual, 8th Edition, Revision A. Chapter 4. Enumeration of Escherichia coli and the Coliform bacteria. http://www.fda.gov/Food/FoodScienceResearch/Labor atoryMethods/ucm064948.htm

[15] FDA BAM 1998d. Bacteriological Analytical Manual, 8th Edition, Revision A. Chapter 5. Salmonella. http://www.fda.gov/Food/FoodScienceResearch/Labor atoryMethods/ucm070149.htm

[16] FDA BAM 1998e. Bacteriological Analytical Manual, 8th Edition, Revision A. Chapter 12. Staphylococcus aureus.

http://www.fda.gov/Food/FoodScienceResearch/Labor atoryMethods/ucm071429.htm

[17] FDA BAM 1998f. Bacteriological Analytical Manual, 8th Edition, Revision A. Chapter 16. Clostridium perfringens.

http://www.fda.gov/Food/FoodScienceResearch/Labor atoryMethods/ucm070878.htm

[18] Luciano, F.B., Belland, J., Holley, R.A., 2011. Microbial and chemical origins of the bactericidal activity of thermally treated yellow mustard powder toward Escherichia coli O157:H7 during dry sausage ripening. International Journal of Food Microbiology, 145: 69-74.

[19] Oflaz, M. 2005. Salmonella contamination in raw and cooked offals. Master Thesis. Health Sciences Institute, Cumhuriyet University, p:59.

[20] Ulutürk, O. 1993.The investigation of Salmonella contamination of edible offal sold for human consumption in the markets of Ankara, Turkey. Master Thesis. Health Sciences Institute, Ankara University, $\mathrm{p}: 42$.

[21] Temelli, S., S.S.Evrensel, Ş. Anar ve M. Tayar, 2002. Determination of the microbiological quality of kokorec samples consumed in Bursa, Turkey. Journal of Faculty of Veterinary Medicine, Istanbul University. 28: 467-473.

[22] Hampikyan, H., Ulusoy, B., Bingöl, E.B., Çolak, H., Akhan, M., 2008. Determination of microbiological quality of some grilled food, salad and appetizers. Turkish Microbiological Society, 38, 87-94.

[23] Kara, R., S. Aslan, H. Yaman ve L. Akkaya, 2013.Determination of microbiological quality of kokorec samples consumed in Afyonkarahisar, Turkey. Kocatepe Veterinary Journal, 6: 7-10.[1]. Reference 1 